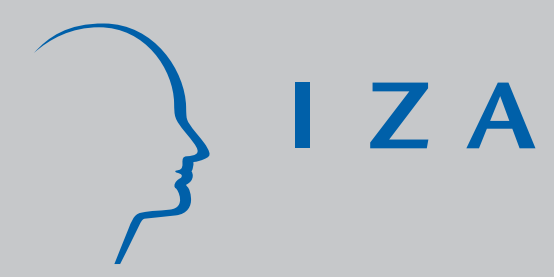

IZA DP No. 2160

Remittances, Financial Development, and Growth

Paola Giuliano

Marta Ruiz-Arranz

J une 2006 


\title{
Remittances, Financial Development, and Growth
}

\author{
Paola Giuliano \\ International Monetary Fund \\ and IZA Bonn \\ Marta Ruiz-Arranz \\ International Monetary Fund
}

Discussion Paper No. 2160

June 2006

\author{
IZA \\ P.O. Box 7240 \\ 53072 Bonn \\ Germany \\ Phone: +49-228-3894-0 \\ Fax: +49-228-3894-180 \\ Email: iza@iza.org
}

\begin{abstract}
Any opinions expressed here are those of the author(s) and not those of the institute. Research disseminated by IZA may include views on policy, but the institute itself takes no institutional policy positions.

The Institute for the Study of Labor (IZA) in Bonn is a local and virtual international research center and a place of communication between science, politics and business. IZA is an independent nonprofit company supported by Deutsche Post World Net. The center is associated with the University of Bonn and offers a stimulating research environment through its research networks, research support, and visitors and doctoral programs. IZA engages in (i) original and internationally competitive research in all fields of labor economics, (ii) development of policy concepts, and (iii) dissemination of research
\end{abstract} results and concepts to the interested public.

IZA Discussion Papers often represent preliminary work and are circulated to encourage discussion. Citation of such a paper should account for its provisional character. A revised version may be available directly from the author. 


\section{ABSTRACT \\ Remittances, Financial Development, and Growth}

Despite the increasing importance of remittances in total international capital flows, the relationship between remittances and growth has not been adequately studied. This paper studies one of the links between remittances and growth, in particular how local financial sector development influences a country's capacity to take advantage of remittances Using a newly-constructed dataset for remittances covering about 100 developing countries, we find that remittances boost growth in countries with less developed financial systems by providing an alternative way to finance investment and helping overcome liquidity constraints. The study also explores some common myths about remittances and suggests that they are predominantly profit-driven and mostly pro-cyclical.

JEL Classification: F22, F43, O16

Keywords: remittances, financial development, growth

Corresponding author:

Paola Giuliano

International Monetary Fund

Research Department

700 19th Street NW

Washington, DC 20431

USA

Email: pgiuliano@imf.org

\footnotetext{
"We would like to thank Oya Celasun, Tito Cordella, Enrica Detragiache, Gianni de Nicolo', Miguel Messmacher, Eswar Prasad, Alessandro Prati, Rodney Ramcharan, Arvind Subramanian, Thierry Thresel for useful comments as well as all the IMF desks for providing us with valuable data and information. The views expressed in this paper are those of the authors and do not necessarily represent the views of the IMF or IMF policy.
} 


\section{Introduction}

Remittances by international migrants to their countries of origin constitute the largest source of external finance for developing countries after foreign direct investment (FDI). Officially recorded remittance inflows amounted to $\$ 125$ million in 2004, exceeding total development aid by 50 percent. In fifteen developing countries, remittances account for more than 10 percent of gross domestic product (Figures 1 to 3). Despite the increasing importance of remittances in total international capital flows, the relationship between remittances and growth has not been adequately studied. This contrasts sharply with the extensive research on the relationship between growth and other sources of foreign capital, such as FDI and official assistance flows ${ }^{2}$. Moreover, the conventional wisdom seems to be that, because remittances are used mostly for consumption, they have a minimal impact on long-term growth.

This paper attempts to fill a gap in the existing literature of the macroeconomic impact of remittances and it also explores some common myths about remittances. This study contributes to the debate of the impact of remittances on growth in two important ways. One, we construct a new measure for remittances, covering about 100 countries, substantially improving data limitations on remittance flows. And two, we analyze the importance of remittances in promoting economic growth, looking specifically at the interaction between remittances and the financial sector, an aspect ignored in the literature. In particular, we explore how local financial sector development influences a country's capacity to take advantage of remittances.

The relationship between remittances, financial development and growth is a-priori ambiguous. On one hand, well-functioning financial markets, by lowering costs of conducting transactions, may help direct remittances to projects that yield the highest return and therefore enhance growth rates. On the other hand, remittances might become a substitute for inefficient or nonexistent credit markets by helping local entrepreneurs bypass lack of collateral or high lending costs and start productive activities. ${ }^{3}$ The empirical analysis finds strong evidence that

\footnotetext{
2 See Alfaro et al. (2004) for an analysis of the relationship between FDI and growth and Easterly (2003) and Rajan and Subramanian (2005) for the link between aid and growth.

3 Entrepreneurs in developing countries confront much less efficient credit markets, and available evidence indicates that access to credit is among their biggest concerns (Paulson and Towsend, 2000).
}

(continued) 
the second channel works: remittances boost growth in countries with less developed financial systems by providing an alternative way to finance investment and helping overcome liquidity constraint. In contrast, while more developed financial systems seems to attract more remittances (the volumes of remittance inflows increase with lower transaction costs and fewer restrictions on payments), they do not seem to magnify their growth impact.

Although this mechanism has not been studied in a macro context, there is some evidence at the micro-level. Dustmann and Kirchamp (2001) find that the savings of returning migrants may be an important source of startup capital for microenterprises. Similarly, in a study of 30 communities in West-Central Mexico, Massey and Parrado (1998) conclude that earnings from work in the United States provided an important source of startup capital in $21 \%$ of the new business formations. Woodruff and Zenteno (2001) also find that remittances are responsible for almost $20 \%$ of the capital invested in microenterprises throughout urban Mexico.

This paper is at the crossroads of two strands of literature. One is the development impact of remittances ${ }^{4}$. Most of the work done on the macroeconomics of remittances and their impact on growth is qualitative and tends to suggest that remittances are mostly spent on consumption, and are not used for productive investment that would contribute to long-run growth. The second strand of literature looks at the determinants of remittances and how the financial sector infrastructure, and in particular transaction costs, influences the propensity to remit. Authors stress the need to promote competition among money transfer operators to reduce transaction costs and stimulate remittances through formal channels. To the best of our knowledge, this is the first paper that analyzes the evidence of complementarity/substitutability between remittances and financial development in promoting growth.

Our empirical analysis suggests that agents compensate for the lack of development of local financial markets using remittances to ease liquidity constraints, channel resources toward productive investments and hence promote economic growth. To assess the merits of our guess,

Several recent papers also suggest that credit constraints play an especially critical role in determining growth prospects in economies characterized by a high level of income inequality (Banerjee and Newman, 1993; Aghion and Bolton, 1997; Aghion, Caroli and Garcia Penalosa, 1999)

${ }^{4}$ Lundhal (1985), Stark (1991), Kirwan and Holden (1986) 
we analyze the interaction of remittances and financial development using a large sample of developing countries. In our analysis we use standard financial market indicators and employ them in growth regressions to study the impact of the interaction of these variables with remittances on economic growth. The result that remittances may play a significant role in promoting growth in countries with shallower financial systems holds true after addressing concerns regarding endogeneity.

A related point in our analysis concerns some common myths about remittances. First, in contrast with conventional wisdom, we present evidence that remittances are not only consumed but also used for investment. And this is particularly prominent in countries where the financial sector does not meet the credit needs of local entrepreneurs. Second, remittances respond as much to economic incentives and investment opportunities in the home country as to altruistic or insurance motives. In about two-thirds of the developing world, remittances are predominantly profit-driven and increase when economic conditions in the home country improve. That is, remittances are mostly procyclical.

The structure of the paper is as follows. Section 2 describes the data; Section 3 is devoted to the empirics of remittances and growth; Section 4 includes several robustness tests. Section 5 analyzes the cyclical behavior of remittances and Section 6 concludes.

\section{Data}

This section describes the data on remittances, financial development, economic growth as well as the control variables used in the growth regressions.

The new remittances variable constructed in this study considers a sample of over 100 countries for the 1975-2002 period. The variable represents an improvement over existing remittances series in several dimensions. Previous studies have generally used a broad definition of remittances that include the following three items in the IMF's Balance of Payment Statistics Yearbook (BOPSY) (all the details are in Appendix 1): workers' remittances, compensation of employees, and migrant transfers. Across the board use of this definition entails the risk of including flows, such as earnings of locals working for foreign embassies and international organizations, which do not conform with the view that remittances typically refer to transfers of money by foreign workers to their home countries. Some other countries do not classify remittances separately from other current transfers in the BOP. In such cases, the standard 
definition understates the true flows. For these reasons, we decided to adopt a country-specific measure of remittances as opposed to a standardized one.

As a first step, we followed the country specific notes in the BOPSY, where in many cases, detailed definitions and description of estimation methodologies are provided. This initial country-by-country inspection concluded that the compensation of employees item needed to be excluded in about 20 countries, since this category did not qualify as remittance flows. As a second step, to estimate flows more accurately and to obtain data for a larger number of countries, we contacted IMF desk economists and country authorities. Some countries have only recently started to produce and report remittances statistics systematically. In these cases, it is common that the IMF desks or country authorities have more information and for a longer time period than the one reported in the BOPSY. Furthermore, in cases where the country notes in BOPSY were insufficient to assess how remittances were measured, they were able to provide clarification regarding definitions and classification of remittances under various BOP items. We obtained information for more than 29 countries (the list is reported in Appendix 1). These additions increased our sample coverage in a substantial way and improved it qualitatively, compared to previous studies. All regressions employ the ratio of remittances to GDP (REM/GDP).

In this study we use four variables to proxy for financial development, all of them related to the banking sector. First, liquid liabilities of the financial system (M2/GDP). They equal currency plus demand and interest bearing liabilities of banks and non-financial intermediaries divided by GDP. It is considered the broadest measure of financial intermediation and includes three types of financial institutions: the central bank, deposit money banks and other financial institutions. Second, the sum of demand, time, saving and foreign currency deposits to GDP (DEP/GDP). It measures the ability of banks to attract financial savings and provide a liquid store of value. Third, claims on the private sector divided by GDP (LOAN/GDP). They measure the extent to which the private sector relies on banks to finance consumption, working capital, and investment. Finally, credit provided by the banking sector to GDP (CREDIT/GDP), which measures how much intermediation is performed by the banking system, including credit to the public and private sectors. The data for the definitions of the variables are obtained from the International Financial Statistics (IFS) of the International Monetary Fund and from the World Development Indicators (WDI) of the World Bank. The 
number of developing countries for which we have data on financial development is also larger than the one used so far (for credits to the private sector all the other datasets have data for only 44 developing countries, compared to our number of 73).

For the first set of regressions, the dependent variable is the growth rate of output, measured as the growth of the real per capita GDP in constant dollars from the WDI. Our set of controls includes (see Table 1 for a definitions and sources of our variables): Inflation, measured as the annual percentage change in the consumption price index. Openness to international trade, defined as the ratio of the sum of exports plus imports of goods to total output. Human capital measured as the average number of years of secondary schooling, obtained from Barro and Lee series. Government fiscal balance and investment ratio defined, respectively, as the ratio of central government fiscal balance to GDP and gross fixed capital formation to GDP; and finally population growth. All control variables, except inflation and fiscal balance, are specified in natural logs.

In the investment regressions, we proxy the user cost of capital by one of two alternative measures: the lending interest rate and the interest rate spread, which is the difference between the lending rate and the deposits rate. Both variables are taken from the WDI dataset.

Our sample consists of 73 developing countries with annual data for the period 19752002. ${ }^{5}$ Following most empirical cross-country studies, we work with a panel of five-year averages of all the variables. Table 2 and Table 3 provide descriptive statistics and bivariate correlations of the variables of interest. Growth, as expected, is positively correlated with investment, government fiscal balance, years of education and our measure of openness, and negatively correlated with inflation. As for our variables of interest, higher remittances are associated with higher growth. Moreover, the correlation between growth and all the measures of financial development is positive, consistent with previous results on the impact of financial development on growth. In turn, remittances are positively associated with investment and openness, and negatively correlated with inflation suggesting that a high rate of domestic inflation may act as a proxy for uncertainty and risk and therefore discourage the flow of

5 We started with a larger dataset, but data for all variables was only available for 73 countries. Furthermore, some observations were excluded following an analysis of outliers. 
remittance earnings. These relations are consistent with previous findings in the literature ${ }^{6}$. Finally, the correlation between remittances and the financial development variables is positive across the four indicators, though very small for loans and bank credit. Although these correlations provide a good initial description of the interrelation among variables, they do not control for other country characteristics and do not imply causality in either direction.

\section{Empirical Analysis}

\section{A Estimation Methodology}

To explore the relationship between remittances, financial development and growth, we work with a pooled (cross-country, time series) dataset consisting of 73 developing countries. We split the sample period 1975-2002 into 6 non-overlapping 5-year periods ${ }^{7}$ (except for the last period for which we average our data for only three years).

As a starting exercise, we estimate the impact of remittances on economic growth by ordinary least squares (OLS). For illustrative purposes, we do not include in our first regression any variable for financial development. We estimate the following equation:

$$
G D P_{i t}=\beta_{0}+\beta_{1} G D P_{i, t-1}+\beta_{2} \operatorname{Rem}_{i t}+\beta_{3} X_{i t}+\mu_{t}+\eta_{i}+\varepsilon_{i t}
$$

where $G D P_{i, t-1}$ denotes the (logarithm of) initial level of GDP per capita, Rem is equal to remittances over GDP and $X_{i t}$ is the matrix of control variables described in the previous section, $\mu_{t}$ is a time specific effect, $\eta_{i}$ is an unobserved country-specific fixed effect and $\varepsilon_{i t}$ is the error term ${ }^{8}$. We are interested in testing whether the marginal impact of remittances on growth, $\beta_{2}$, is statistically significant.

\footnotetext{
${ }^{6}$ See El-Sakka and Mcnabb (1999) and Detragiache et al. (2005).

${ }^{7}$ We use 5-year periods rather than shorter time spans because although the financial development data are available on a yearly basis for most countries in our sample, they might be subject to business cycle fluctuations, which we can be controlled for by averaging over longer time periods.
}

8 Note that equation (1) can be alternatively written with the growth rate as dependent variable as: Growth $_{i t}=G D P_{i t}-G D P_{i, t-1}=\beta_{0}+\left(\beta_{1}-1\right) G D P_{i, t-1}+\beta_{2} \operatorname{Rem}_{i t}+\beta_{3} X_{i t}+\mu_{t}+\eta_{i}+\varepsilon_{i t}$, where $\left(\beta_{1}-1\right)$ is the convergence coefficient. 
While remittances have the potential to affect economic activity through a host of channels, in a second set of regressions we examine one specific link between remittances and growth, specifically that working through financial markets. The hypothesis we would like to test is whether the level of financial depth in the recipient country affects the impact of remittances on growth. To this end, we interact the remittances variable with an indicator of financial depth and test for the significance of the interacted coefficient ${ }^{9}$. A negative coefficient would indicate that remittances are more effective in boosting growth in countries with shallower financial systems. In other words, a negative interaction provides evidence of substitutability between remittances and financial instruments. On the other hand, a positive interaction would imply that the growth effects of remittances are enhanced in deeper financial systems, supporting complementarity of remittances and other financial flows.

The regression to be estimated is the following:

$$
\begin{aligned}
G D P_{i t}=\beta_{0} & +\beta_{1} G D P_{i, t-1}+\beta_{2} \operatorname{Re}_{i t}+\beta_{3} \operatorname{FinDev}_{i t}+ \\
& +\beta_{4}\left(\operatorname{Rem}_{i t} \cdot \operatorname{FinDev}_{i t}\right)+\beta_{5} X_{i t}+\mu_{t}+\eta_{i}+\varepsilon_{i t}
\end{aligned}
$$

Our first sets of OLS regressions, with or without the interaction with financial development, do not address issues regarding endogeneity. Theoretically, however, it is plausible, and also very likely, that both the magnitude of remittances and the efficiency of financial markets increase with higher growth rates. This would lead to an overstatement of the effect of each of the two variables and their interaction on growth. There has been an extensive search for good instruments for financial development. In the literature, variables not subject to reverse causality, such as origins of a country's legal systems and creditor rights (La Porta et al., 1997) are commonly used. Rajan and Subramanian (2005) use the distance from the country of origin as an instrument for remittances. These variables suffer from the drawback that they do not vary over time, so we cannot use them in a panel framework. Therefore, we address the endogeneity problem looking at panel system Generalized Method of Moments regressions (SGMM), following Arellano and Bover (1995). ${ }^{10}$

\footnotetext{
9 In order to ensure that the interaction term does not proxy for remittances or the level of development of financial markets, these variables are also included in the regression separately.

${ }^{10}$ For a discussion of the reason why a system GMM estimator outperforms a difference GMM estimator see Arellano and Bover (1993) and Blundell and Bond (1997).
} 


\section{III.B Estimation Results}

Table 4 reports estimates of equation (1) using various econometric techniques (OLS, FE and SGMM). It shows that the impact of remittances on growth is practically nil when the remittances variable is simply added as an additional explanatory variable in a standard growth regression. While the coefficient estimates increase and become marginally significant when investment is dropped from the specification ${ }^{11}$, the empirical evidence in favor of a positive role of remittances on growth seems to be at most fragile. These results contrast with some recent literature at the micro level, which has identified positive effects of remittances on consumption, investment, years of education, and health outcomes. This poses the question of whether the impact of remittances is homogeneous across countries or whether it varies along a dimension, which has not been properly accounted for in the estimated specification. We next investigate this avenue. In particular, we explore whether the financial development of the recipient country influences the specific uses given to remittances and their capacity to influence growth.

To this end, we estimate equation (2), which allows the impact of remittances on growth to vary across levels of financial development in the recipient country. The sign of the interacted coefficient provides information regarding the nature of remittances. More specifically, a positive interaction term reveals that they are complementary and that a well functioning financial system enhances the impact of remittances. On the other hand, a negative sign indicates that remittances and financial depth are used as substitutes to promote growth.

Tables 5 and 6 present OLS and SGMM estimates of (2) respectively. We focus our discussion on the latter but it is worth noting that the two are qualitatively and quantitatively very similar. In all regressions, two lags of all endogenous variables are used as instruments for all non strictly exogenous variables, including the remittances and financial depth indicators. In addition, autocorrelation tests and the Hansen test of overidentifying restrictions are performed to assess the validity of the instruments employed. We estimate (2) for each of our measures of financial depth and find that results are consistent across the four indicators (i.e. across columns in the table).

11 This is done in an attempt to better capture the impact of remittances by omitting one of the channels though which remittances are likely to affect growth, that is investment. The results are available upon request from the authors. 
The main results are easily summarized. We find strong evidence of a positive and significant coefficient of remittance flows and of a negative interaction between remittances and financial depth. These findings suggest that the marginal impact of remittances on growth is decreasing with the level of financial development. In other words, remittances have contributed to promote growth in countries with shallower financial systems. In contrast, in more developed financial systems, remittances do not seem to magnify their growth impact.. By relaxing liquidity constraints, remittances have compensated for the lack (or the inefficiency) of the financial system and have contributed to channel resources toward productive investments. Remittances have de facto act as a substitute for financial services in promoting growth, by offering the response to the needs for credit and insurance that the market has failed to provide.

Table 7 indicates that remittances have a positive impact on growth at both the mean and median level of financial development but this becomes zero -and eventually turns negativein countries with well developed financial systems (above the 75th percentile of the distribution of the financial variable). In terms of magnitudes, an increase by one percentage point in the deposits to GDP ratio from the median level of 29 percent would enhance growth by 0.18 percentage points. Similarly, the marginal effect of remittances is 0.19 at the median loans to GDP ratio, 0.09 at the median banking sector credit ratio and 0.20 at the median M2 to GDP level. However, these effects can be twice as large in the presence of stringent lending and borrowing restrictions.

On the other hand, with limited capital market imperfections, remittances are not essential to finance investment, as the needs for credit and insurance can be met by a well functioning banking system. In this case, remittances are more likely to be devoted to non growth generating activities, such as conspicuous consumption, or might even discourage labor supply on the side of the recipients and hence reduce growth. This can explain why the impact of remittances declines with financial depth. In turn, the possibility of the marginal impact becoming negative at very high levels of financial development can be argued on moral hazard grounds, along the paper by Chami et al.

Consistent with previous literature, we also find that financial development facilitates economic growth. With regards the effect of the other variables in the regression, they are all consistent with standard growth regression results. Population, inflation and initial GDP are negative and significant, whereas investment ratio and years of schooling help boost economic 
growth. Fiscal balance does not appear to have a significant impact on growth in most regressions, with the exception of SGMM, where is negative and significant but only at the 10 percent level.

In all the different specifications used, the Sargan test and the second order correlation tests indicate that we cannot reject the validity of the moment conditions assumed for the estimation.

In an attempt to identify the channels through which remittances affect growth, we also estimate the growth regressions dropping investment as an explanatory variable ${ }^{12}$. If the marginal impact of remittances becomes larger, this would provide indirect evidence of a channel working through productive investment. Table 7 shows that this is indeed the case. The marginal impact of remittances at the median and mean levels of financial development increases by about 50 percent in the case of deposits and M2 to GDP. The increase is between 2 and 6 times larger in the case of total credit from the banking sector. These results suggest that an important channel through which remittances influence growth is the volume of investments. The other potential channels may be the efficiency of investments, investment in human capital as well as multiplicative effects from higher savings and internal demand.

To explore the empirical relation between remittances and investment in a more direct way, we estimate the following investment equation:

$$
\begin{aligned}
I N V G D P_{i t}= & \beta_{0}+\beta_{1} I_{N V G D P} P_{i, t-1}+\beta_{2} \operatorname{Re} m_{i t}+\beta_{3} \text { FinDev }_{i t}+ \\
& +\beta_{4}\left(\operatorname{Rem}_{i t} \cdot \operatorname{FinDev}_{i t}\right)+\beta_{5} Z_{i t}+\mu_{t}+\eta_{i}+\varepsilon_{i t}
\end{aligned}
$$

where INVGDP is total investment to GDP and $Z$ is a matrix of controls, which includes per capita real GDP growth to capture the accelerator effect and a measure of the user cost of capital, proxied by the lending interest rate. The remaining variables are defined as above. One expects that growth exerts a positive effect on investment and that higher lending rates hamper the rate of capital accumulation. We have also estimated this equation adding other potential determinants of investment, in particular inflation and openness but the main results

12 The financial development variable is likely to be affected when investment is eliminated from the regression as well. According to Barro, the investment ratio can bias the results due to reverse causality. Some studies on financial development include the investment variable (see Alfaro, 2004), while others decide to leave it out (see Loayza and Ranciere, 2005). 
hold across different variations of the basic specification. In the interest of simplicity, we discuss the results that emerge from the estimation of equation (4), which uses the most conventional determinants of investment only.

Estimation results are reported in Table 8. For each column, indicating the use of a different financial development indicator, the estimated coefficient of the lagged investment variable is large and positive. In turn, the output growth elasticity of investment is also positive and significant. While the coefficient corresponding to the lending interest rate carries the anticipated negative sign, this is not statistically significant. We get similar results if we use the interest rate spread -the difference between the lending rate and the deposits rate- as a measure of the user cost of capital. Regarding the remittances variable, it is remarkable that this is positive and significant across all specifications. Also in accordance with the results previously found, the interaction between remittances and financial depth is negative and significant. These results imply that the marginal impact of remittances on investment is positive across largely all levels of financial development ${ }^{13}$. However, the largest remittances-driven increases in investment have taken place in less financially developed countries. While the marginal impact of remittances on investment ranges between 0.2 and 0.4 at the median level of financial development, the impact can surpass 0.5 at the lowest quartile of the distribution of financial development. Unlike the growth regressions, the investment regressions do not show an independent statistically positive effect of financial development.

Finally, the diagnostic tests (Hansen and first and second order autocorrelation) reveal no evidence against the validity of the instruments used by the SGMM estimator.

To summarize the empirical exercise of this section, the econometric analysis reveals a significant positive impact of remittances on growth and investment once the interaction with financial development is accounted for. The overriding result is the statistical negative significance of the interaction term, indicating that remittances and financial development have been used as substitutes to promote economic growth.

The presence of liquidity constraints impinges investment in physical and human capital, in particular in those developing countries where access to credit and insurance is limited and

13 The marginal effect of remittances only becomes zero at very high levels of financial depth, beyond the 90-95 percentile of the distribution. 
expensive. Remittances have played the role of alleviating these liquidity constraints, by financing investment and enhancing growth and might have also been instrumental to achieving insurance and consumption smoothing. In contrast, where the financial system was developed enough, remittances have had a much lower impact on growth, even possibly negative. In this case, the financial system was sufficient to meet financing needs for investment, and remittances were used for purposes that did not foster growth.

\section{Robustness: Threshold Estimation}

A simple robustness test consists of splitting the sample according to the level of financial development and compare the impact of remittances across sub-samples. In light of the main result of the empirical analysis, we should find a larger impact of remittances in the subsample of countries where the financial system is less developed. We split the sample in two ways. First, exogenously according to the median level and second based on an endogenously determined threshold.

Table 9 presents SGMM growth estimates for countries above and below the median of financial development. These results tend to reinforce our previous findings. More specifically, we find that the impact of remittances is positive for the sample of countries with low financial development (below the median level) and it is nil or negative for countries with deeper financial systems. Nonetheless, using a standard t-test we are only able to reject the hypothesis that the marginal impact of remittances is equal across sub-samples in one case..

Following Hansen (1996 and 2000) ${ }^{14}$, we use threshold estimation as an alternative robustness test. Threshold estimation has been applied for nonparametric function estimation as well as for empirical sample splitting when the sample is based on a continuously distributed variable. Instead of (exogenously) selecting the sub-samples based on the median level of financial development, threshold estimation allows to endogenously determine the threshold level of financial development at which the sample should be split. Therefore, this is a better strategy to determine the threshold level of financial development at which the relation between

14 Gauss programs of the applications in these papers can be found at http://www.ssc.wisc.edu/ bhansen/ 
growth and remittances changes, its confidence interval and the impact of remittances across regimes. Threshold estimation takes the form

$$
\begin{array}{cc}
G D P_{i t}=\beta_{0}+\beta_{1} G D P_{i, t-1}+\beta_{2} \operatorname{Rem}_{\mathrm{it}}+\beta_{3} \operatorname{FinDev}_{i t}+\beta_{4} X_{i t}+\mu_{t}+\eta_{i}+\varepsilon_{i t} & \text { FinDev }_{i t} \leq \gamma \\
G D P_{i t}=\alpha_{0}+\alpha_{1} G D P_{i, t-1}+\alpha_{2} \operatorname{Rem}_{\mathrm{it}}+\alpha_{3} \operatorname{FinDev}_{i t}+\alpha_{4} X_{i t}+\mu_{t}+\eta_{i}+\varepsilon_{i t} & \text { FinDev }_{i t}>\gamma
\end{array}
$$

where FinDev is the threshold variable used to split the sample into two groups ${ }^{15}, \gamma$ is the endogenously determined threshold level. This model allows the regression parameters to differ depending on the value of FinDev. Hansen (2000) derives an asymptotic approximation to the distribution of the least-squares estimate of the threshold parameter, which allows testing for the existence of a threshold. ${ }^{16}$

Estimates of the threshold model, including the threshold parameter and the least square coefficients on each sub-sample, are reported in Table 10. We compute confidence intervals for the regression parameters and the threshold coefficient, and provide an asymptotic simulation test of the null of linearity against the alternative of a threshold. The estimated threshold of deposits is 22.6 percent of GDP, with a 95 percent confidence interval [11, 73]. That of claims to the private sector is 20.8 , with a 95 percent confidence interval $[16,22]$. The estimated threshold of banking credit occurs at 30 percent and the confidence interval is [29, 33]. Finally, estimation using M2 to GDP produces a threshold at 20.8 percent, with a confidence interval $[16,22]$. Incidentally, the estimated threshold levels are relatively similar to the median values of the corresponding financial development variables, except for M2/GDP, where is lower.

The test of the null hypothesis of no threshold against the alternative of threshold is performed using a Wald test under the assumption of homoskedastic errors ${ }^{17}$. Using 1000

\footnotetext{
15 The threshold variable could be the dependent variable, a regressor or a third variable, not included in the regression, and it is assumed to have a continuos distribution.

16 This approach derives OLS estimates and does not correct for endogeneity. We are not aware of any attempt to find such a distribution for SGMM estimates. Nevertheless the exercise still provides interesting insights, especially in view of the similarities between OLS and SGMM estimates suggested by our previous findings.

17 We also compute heteroskedastcity-consistent Lagrange multiplier tests for a threshold, as in Hansen (1996). In general, they suggest the same sample split as the tests assuming homoskedasticity. We present
}

(continued) 
bootstrap replications, the p-value for the threshold model is very close to zero in each case. There is, therefore, evidence for a regime change at the determined level of financial development. Estimates of the growth regression model for each sub-sample indicate that the marginal impact of remittances is not statistically different from zero in the high financial development regime. On the other hand, remittances have a larger positive impact, and often statistically significant, in the low-financial development sub-sample. It is worth noting that most of the controls in the growth regression, not only the remittances variable, behave differently across sub-samples.

To summarize, our robustness checks consisted of splitting the sample according to the degree of financial depth and comparing the impact of remittances on growth across subsamples. First, we split countries in the sample in an exogenous manner, more specifically, according to the median level of financial development. Second, we split the observations in our sample according to an endogenously determined threshold. Results are consistent across methodologies and confirm the findings of the previous section, namely that remittances have a larger impact on growth in shallower financial systems. On the other hand, remittances do not seem to have an impact on financially developed countries.

\section{Cyclical Behavior of Remittances: Profit-Driven Capital Flows or Compensatory Transfers?}

By providing evidence that remittances promote investment, prominently in countries with weak financial sectors, the previous sections have contributed to somehow overid the conventional wisdom that remittances are used mostly for consumption. In this section, we explore a second common myth, namely that remittances tend to be more stable and less affected by economic cycles in the recipient country than other capital flows. Since there is no rigorous analysis supporting this evidence, we present the first systematic effort to document empirically the cyclical properties of remittances.

the latter ones because the threshold which maximizes the Wald statistic under homoskedasticity is the same as the one which minimizes the least-squares criterion. 
In the second part of this section we analyze how the cyclicality of remittances is associated to the depth of the financial system. Are remittances more likely to be procyclical in more or less financially developed countries? In other words, does financial development smooth or amplify the cyclicality of remittances? This part will then provide indirect supportive evidence for the channels through which remittances can promote growth, outlined in this paper.

To assess the cyclical properties of remittance flows, we follow the Hodrick-Prescott filtering technique, commonly used in the literature and consisting of decomposing the time series of output and remittances into their stochastic trend and cyclical component. Following Kaminsky, Reinhart and Vegh (2004), we define remittances as countercyclical, procyclical or acyclical when the correlation between the cyclical component of remittances and output is negative/ positive or not statistically significant, respectively.

Figure 4 shows the correlations of the cyclical components of remittances and output for about a hundred developing countries. It is apparent from the figure that remittances are procyclical -to different degrees- for two thirds of the countries ${ }^{18}$. In principle, this correlation could have any sign, since migrants could send remittances when their home country is booming in order to take advantage of the good state of the economy; or in bad times, for altruistic and insurance motives, to help out their family members. There is, thus, some indication that migrants tend to send remittances when the economic situation in the country of origin is favorable, possibly in search of investment opportunities. This investment channel is probably the most important channel to explain our results about the positive link between remittances and growth.

We now turn to the second question of this section: whether more developed financial systems are associated with more or less procyclicality of remittances. If remittances are more compensatory in nature (i.e. if they are sent for altruistic reasons in order to help the family in the home country), they should be negatively correlated with the home country GDP, or countercyclical. In contrast, if they are profit-driven, they should be positively correlated with GDP, or procyclical. That is, a larger procyclicality of remittances is associated with the search

\footnotetext{
18 At the aggregate level, the average across all countries, weitghing them equally, is about 0.1 .
} 
of investment opportunities (i.e. profit-driven remittances) rather than with an insurance or altruistic motive to remit (i.e. compensatory transfers). Because profit-driven remittances are more likely to be invested and altrusitic-driven remittances more likely to be consumed, we would expect remittances to have a greater impact on growth where remittances are more procyclical. This assesment together with the finding of the previous section-remittances are most effective in less financially developed countries-, implies that we should expect remittances to be more procyclical in countries with shallower financial systems.

The hypothesis that procyclicality of remittances is larger in shallower financial systems is tested computing correlation coefficients between the following two indicators: one, the median over the 1975-2002 period of financial development -measured by deposits, banking credit, claims to the private sector or M2 to GDP- and two, the series of correlations displayed in Figure 4, representing the cyclical behavior of remittances with respect to output. We also estimate bivariate regressions of the cyclical indicator of remittances on each of the financial development measures.

Table 11 shows that all correlations and estimation coefficients are negative across all measures of financial development and range from -0.13 to -0.35 . Furthermore, all coefficients are significant at the 10 percent level, except for those associated to the banking credit variable. This indicates that countries where remittances are more procyclical are associated with less developed financial systems and it is consistent with the main conclusion of the paper, that of substitutability between remittances and the financial sector.

It is worth noting that this evidence suggests a rather interesting, and a priori paradoxical result, namely that remittances tend to be more countercyclical -that is, more compensatory transfers in nature- in countries with deeper financial systems, where agents could, in principle, get insured against bad shocks more easily. On the other hand, remittances are more likely to seek investment opportunities by responding to the home country economic conditions in countries with less developed financial sectors, where doing business could be more difficult. Thus, financial depth smoothes or counter-balances the cyclicality of remittances.

\section{Conclusions}

What is the macroeconomic impact of remittances? Is there evidence that remittances foster productive investment? How does financial development influence the growth effects of 
remittances? To shed some light on these important questions, in this paper we analyzed the relationship bewteen remittances and growth and its interaction with the financial development in the recipient country. We used a newly constructed cross-country series for remittances covering a large number of developing countries over the period 1975-2002. We find that remittances have promoted growth in less financially developed countries by providing an alternative way to finance investment. This finding controls for the endogeneity of remittances and financial development using a SGMM approach, does not depend on the particular measure of financial sector development used, and is robust to a number of robusteness tests. By becoming a substitute for inefficient or inexistent credit markets, remittances help alleviate credit constraints contributing to improve the allocation of capital and to boost economic growth. The findings suggest that there is an investment channel trough which remittances can promote growth where the financial sector does not meet the credit needs of the population. We also analyzed the cyclical properties of remittances and concluded that they are predominantly profitdriven and mostly procyclical.

These findings do not, however, give insights on all the channels through which remittances may affect growth. In particular, we did not explore other possible measures of countries' characteristics, including institutional aspect that may explain this effect. It is possible, for example, that factors other than the degree of financial development may explain why remittances can have an impact on growth. Although this type of omitted variable problem is reduced given our specification, we cannot eliminate the possibility that omitted variables drive some of the results. We did not explore in great detail the potential moral hazard implications of remittances either. Nonetheless, we interpret the nil or even negative impact of remittances at high levels of financial development as suggestive evidence that remittances are more likely to discourage labor supply in more financially developed countries.

Overall, our empirical analysis provides the first macroeconomic evidence of how remittances and financial development may interact in promoting growth. The evidence that remittances contribute to overcome liquidity constraints and help undertake profitable investment in countries with less developed financial systems is encouraging. But while many policy-makers stress the need to stimulate remittances across the board by reducing transfer costs, the biggest challenge is to understand why remittances do not seem to boost growth in 


\section{References}

Adams, R., 1989, "Workers Remittances and Inequality in Rural Egypt", Economic Development and Cultural Change, 38, 1: 45-71

Adams, R., 1992, “The Impact of Migration and Remittances on Inequality in Rural Pakistan", Pakistan Development Review, 31, 4: 1189-2203

Adams, Richard, and John Page, 2003, "International Migration, Remittances and Poverty in Developing Countries," World Bank Policy Research Working Paper 3179.

Adams, Jr., Richard, 1991, "The Effects of International Remittances on Poverty, Inequality and Development in Rural Egypt,” Research Report 86. International Food Policy Research Institute, Washington, DC.

Adams, Jr, Richard, 1998, "Remittances, Investment and Rural Asset Accumulation in Pakistan," Economic Development and Cultural Change, 47 (1): 155-173.

Adams, Jr., Richard, 2003a. “Economic Growth, Inequality and Poverty: Findings from A New Data Set," World Bank Policy Research Working Paper 2972. Washington, DC.

Adams, Jr., Richard, 2003b, "International Migration, Remittances and the Brain Drain: A Study of 24 Labor-Exporting Countries," World Bank Policy Research Working Paper 3069. Washington, DC.

Aghion, P. and P. Bolton, 1997, "A Theory of Trickle-Down Growth and Development", Review of Economic Studies 64(2): 151-172.

Aghion, P, E. Caroli and C. Garcia-Penalosa, 1999, "Inequality and Economic Growth: The Perspective of the New Growth Theories", Journal of Economic Literature, Vol. 37(4), pp. 1615-1660.

Alfaro, L., A. Chanda, S. Kalemli-Ozean, S. Sayek, 2004 "FDI and Economic Growth: the Role of Local Financial Markets," Journal of International Economics 64, 89-112

Banerjee, A. V. and A. Newman, 1993, "Occupational Choice and the Process of Development," Journal of Political Economy, 101, 274-298

Barham, B. and S. Boucher, 1998, "Migration, Remittances and Inequality: Estimating the Net Effects of Migration on Income Distribution”, Journal of Development Economics, 55: 307-31

Beck, T., R. Levine, N. Loyaza, 2000, "Finance and the Sources of Growth,” Journal of Financial Economics 58, 261-300.

Chami, R., C. Fullenkamp, and S. Jahjah, 2003, "Are Migrant Remittance Flows a Source of Capital for Development?," IMF Working Paper, International Monetary Fund, Washington D.C.

Chandavarkar, A. B., 1980, "Use of Migrants' Remittances in Labor-Exporting Countries," Finance and Development 17 (June).

Cox Edwards, Alejandra, and Manuelita Ureta, 2003, "International Migration, Remittances, and Schooling: Evidence from El Salvador," NBER Working Paper 9766. 
Detragiache, E., P. Gupta, and T. Thressel, 2005, "What Explains Financial Sector Development and Performance in Lower Income Countries,? Mimeo IMF

Djajic, S., 1986, "International migration, remittances and welfare in a dependent economy", Journal of Development Economics, 21: 229-234

Dustmann, C. and O. Kirchamp, 2001, "The Optimal Migration Duration and Activity Choice after Re-Migration”, IZA Discussion Paper 266.

Easterly, W. 2003, “Can Foreign Aid Buy Growth?”, Journal of Economic Perspective, Vol. 17, no. 3: 23-48.

El-Qorchi, Mohammed, Maimbo, Samuel and Wilson, John, 2003, "Informal Funds Transfer Systems: An Analysis of the Informal Hawala System,” Occasional Paper 222. International Monetary Fund, Washington, DC.

El-Sakka, M., R. McNabb, 1999, “The Macroeconomic Determinants of Emigrant Remittances,” World Development, 27(8), 1493-1502.

Galor, O., Zeira, J. "Income Distribution and Macroeconomics," Review of Economic Studies, 60: $35-52$

Greenwood and Jobanovic, 1990, "Financial Development, Growth and the Distribution of Income," Journal of Political Economy, 98, 1076-1107

Hansen, B. 2000, "Sample Splitting and Threshold Estimation," Econometrica, Vol. 68, No. 3, (May 2000), 575-603.

Hansen, B., 1996, "Inference When a Nuisance Parameter is Not Identified Under the Null Hypothesis," Econometrica, Vol. 64, No. 2 (March, 1996), 413-430.

King, R., Levine, R. 1993, "Finance, Entrepreneurship and Growth: Theory and Evidence," Journal of Monetary Economics 32, 513-542

Kirwan, F. and D. Holden, 1986, "Emigrants' Remittances, Non-Traded Goods and Economic Source in the Source Country", Journal of Economic Studies, Vol. 13, n. 2: $52-58$

Levine, R., Loyaza, N., Beck, T., 2000, "Financial Intermediation and Growth: Causality and Causes," Journal of Monetary Economics, 31-77

Loayza, N., R. Ranciere, 2004, “Financial Development, Financial Fragility and Growth,” Policy Research Working Paper 3431, The World Bank

Lucas, R., 1987, "Emigration to South Africa's Mines," The American Economic Review, Vol. 77 no. 3, 313-330

Lundhal, M., 2005, "International Migration, Remittances and Real Incomes: Effects on the Source Country", Scandinavian Journal of Economics 87(4): 647-657

Massey, D. and E. Parrado, 1998, "International Migration and Business Formation in Mexico", Social Science Quarterly, 79 (1), 1-20

McConrmick and Wahba, 2000, "Overseas Employment and Remittances to a Dual Economy," The Economic Journal, vol. 100 no 463, 509-534

Organization for Economic Cooperation and Development (OECD), Various years, Trends in 
International Migration: Annual Report, Paris, France.

Organization for Economic Cooperation and Development (OECD), 2004, Working Abroad: the Benefits Flowing from Nationals Working in Other Economies, available at: www.oecd.org/dataoecd/30/20/32297831.pdf (Paris, France).

Paulson, A. and R. Towsend, 2000, "Entrepreneurship and Financial Constraints in Thailand", Working Paper, Northwestern University

Rajan, R. and A. Subramanian, 2005, "What Undermines Aid's Impact on Growth?”, IMF Working Paper no. 05/126.

Rapoport, H. and f. Docquier, 2005, "The economics of Migrants' Remittances", Handbook on the Economics of Reciprocity, Giving and Altruism, forthcoming

Ratha, Dilip, 2003, "Workers' Remittances: An Important and Stable Source of External Development Finance," Global Development Finance 2003 - Striving for Stability in Development Finance Ch. 7: 157-175 (Washington, DC: World Bank).

Rozelle, S., Taylor, E. and deBrauw A. (1999), "Migration, Remittances and Agricultural Productivity in China," American Economic Review, Vol. 89 no. 2, 287-291

Russell, Sharon, 1986, "Remittances from International Migration: A Review in Perspective," World Development, 14 (6): 677-696.

Stark, O., 1991, The Migration of Labor, Oxford and Cambridge, MA: Basil BAckwell

Taylor, J. Edward and Adelman, Irma, 1996, "Village Economies: The Design, Estimation and Use of Villagewide Economic Models" (Cambridge: Cambridge University Press)

Taylor, J. and T. Wyatt, 1996, "The Shadow Value of Migrant Remittances, Income and Inequality in a Household-Farm Economy", Journal of Development Studies, 32, 6: 899-912

United Nations, 2002, International Migration Report 2002, Department of Economic and Social Affairs, Population Division. New York, NY.

Woodruff, C. and R. Zenteno, 2001, "Remittances and Micro-Enterprises in Mexico", mimeo, University of California San Diego

World Bank, 2001, World Development Report, 2000/01, Washington, DC. 
Figure 1. Remittances, Official flows and FDI, 1975-2003

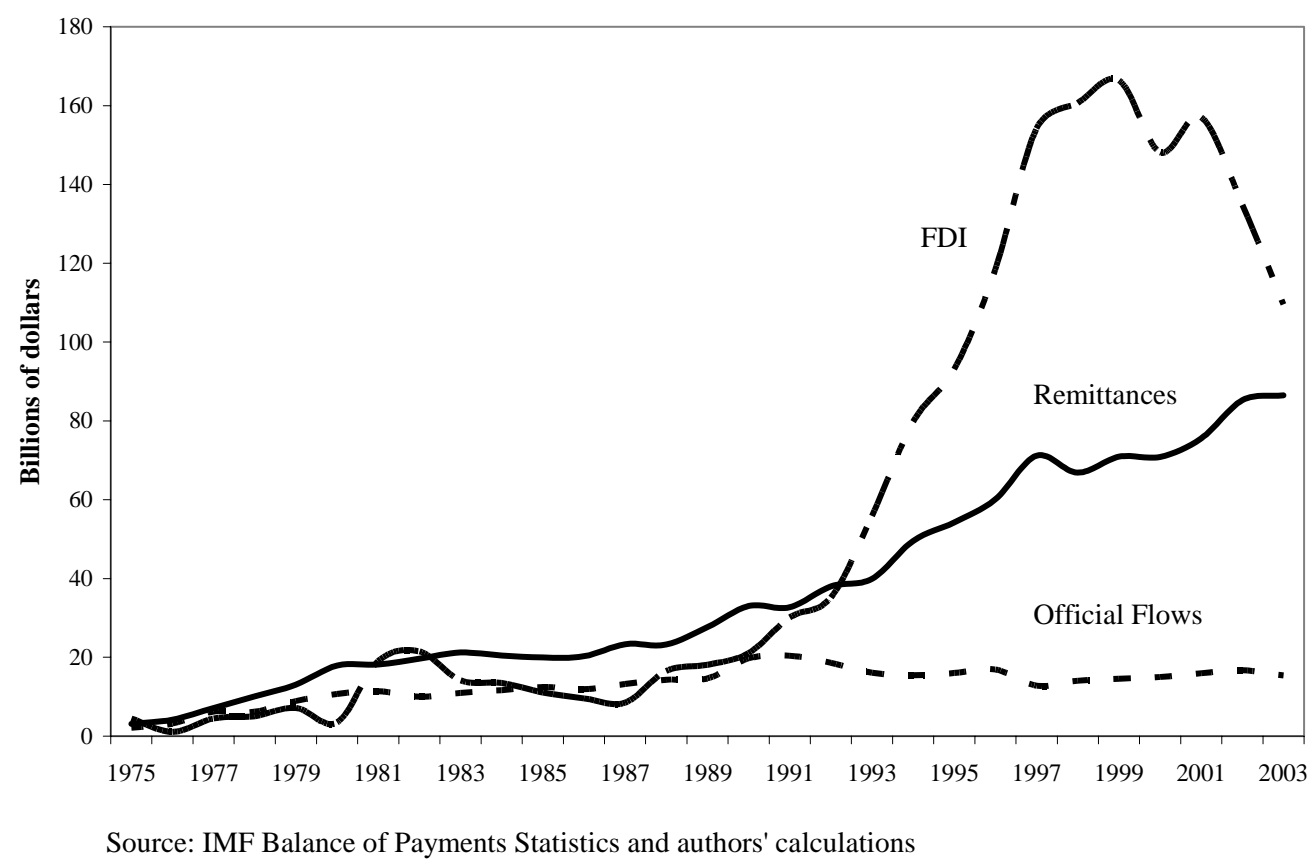

Figure 2. Remittances, Official flows and FDI, 1975-2003

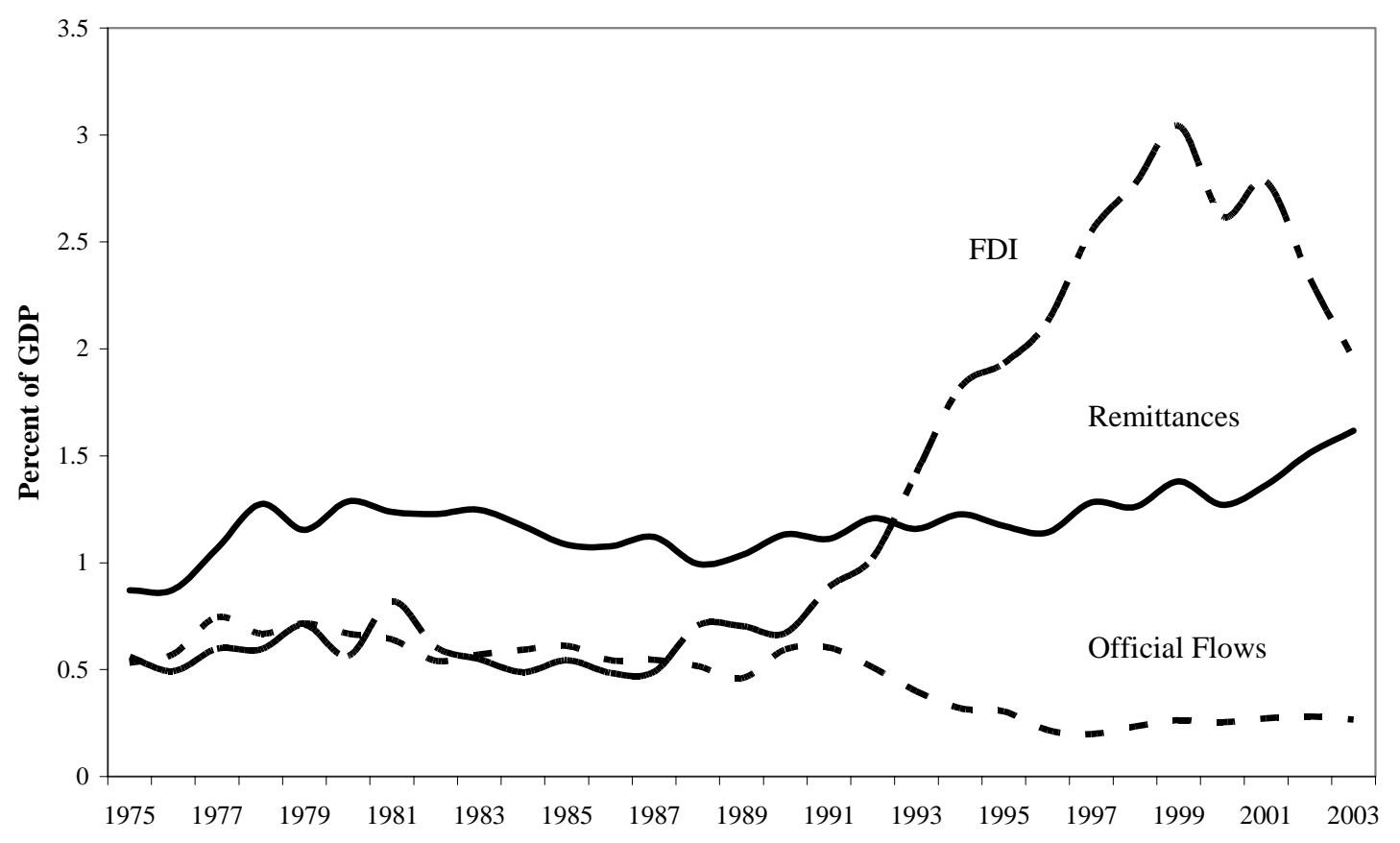

Source: IMF Balance of Payments Statistics and authors' calculations 
Figure 3. Largest Recipients of Remittances in $\mathbf{2 0 0 2}$

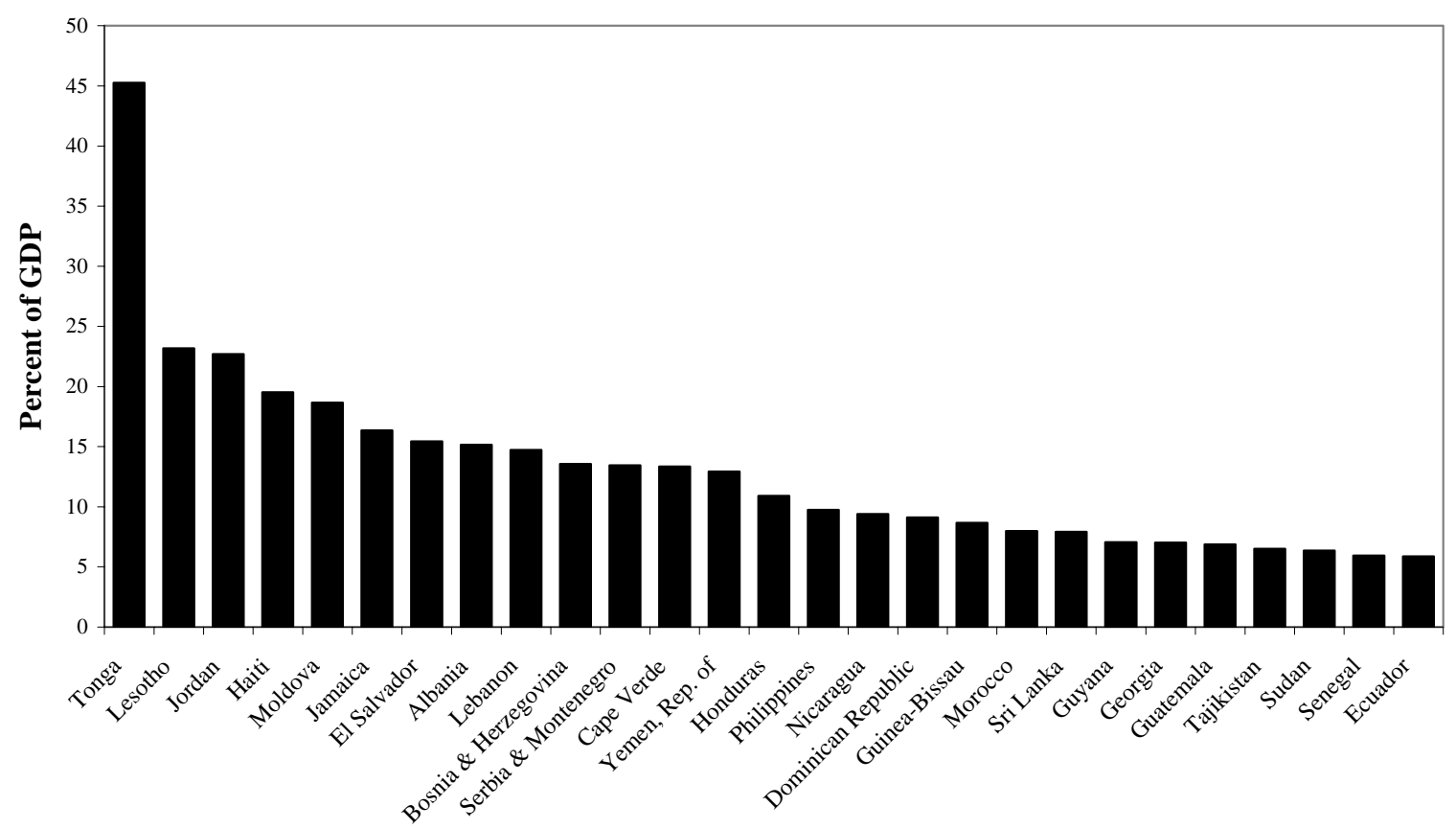

Source: IMF Balance of Payments Statistics and authors' calculations 
Figure 4. Country Correlations between the Cyclical Components of Remittances and GDP 1975-2002

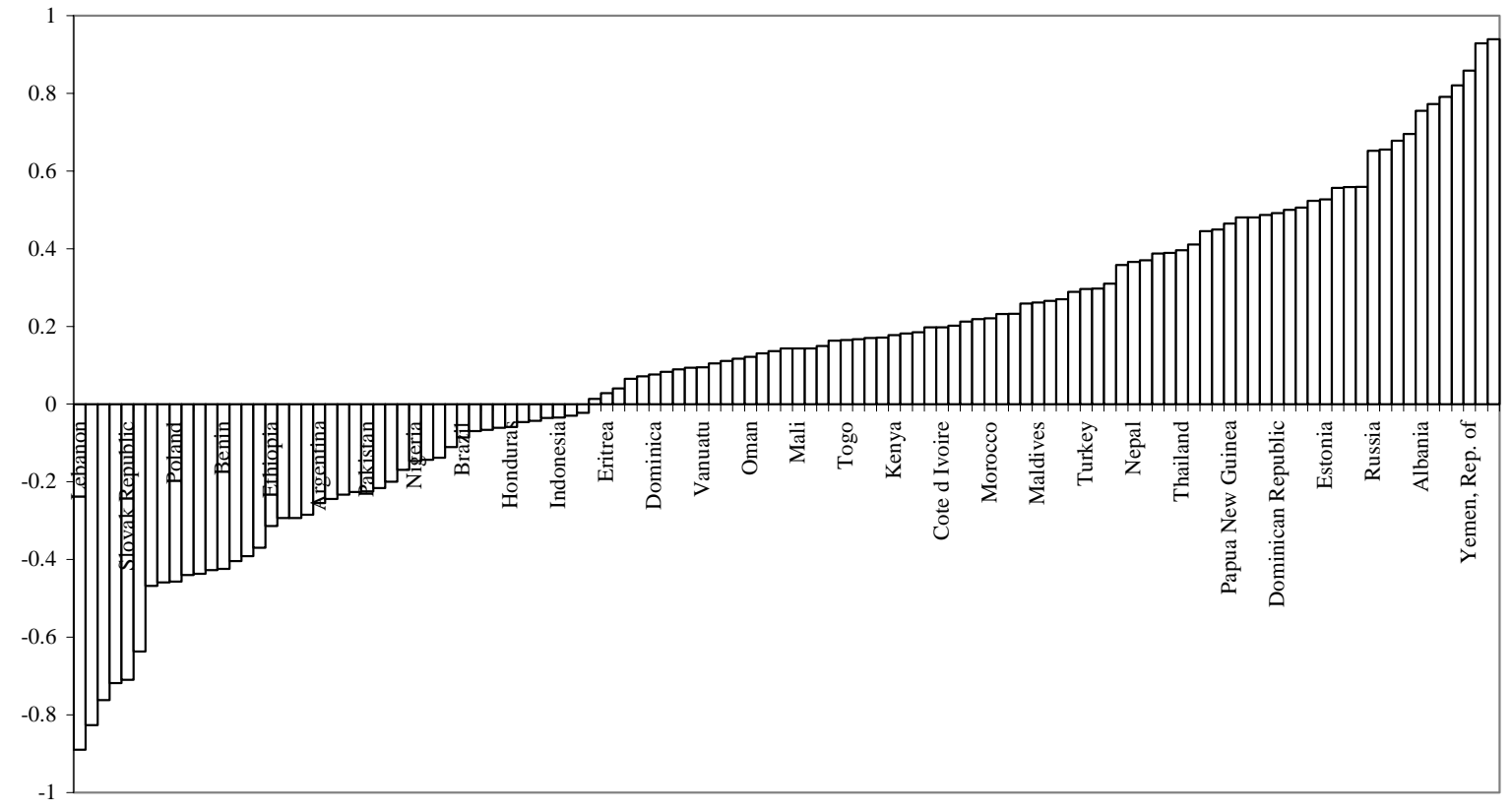

Souce: IMF Balance of Payment Statistics and Authors' Calculations 
Table 1. Definition and source of the variables

\begin{tabular}{|c|c|}
\hline Variable & Description \\
\hline Growth & $\begin{array}{l}\text { Growth of real percapita GDP in constant dollars. } \\
\text { Source: World Development Indicators, World Bank. }\end{array}$ \\
\hline Remittances/GDP & $\begin{array}{l}\text { Remittances are defined as sum of three } \\
\text { components. Details on Appendix 1. Source: Balance } \\
\text { of Payment Yearbook, International Monetary Fund. }\end{array}$ \\
\hline Investment/GDP & $\begin{array}{l}\text { Gross Fixed Capital Formation as a share of GDP. } \\
\text { Source: Word Development Indicators, World Bank. }\end{array}$ \\
\hline FiscalBalance/GDP & $\begin{array}{l}\text { Fiscal balance of the central government as a share of } \\
\text { GDP. Source: Word Development Indicators, World } \\
\text { Bank. }\end{array}$ \\
\hline Openness & $\begin{array}{l}\text { Exports plus imports as a share of GDP. Source: } \\
\text { World Development Indicators, World Bank. }\end{array}$ \\
\hline Inflation & $\begin{array}{l}\text { Annual Percentage change in CPI. Source: World } \\
\text { Economic Outlook, International Monetary Fund }\end{array}$ \\
\hline Population growth & $\begin{array}{l}\text { Log difference of Population. Source: World } \\
\text { Development Indicator, World Bank }\end{array}$ \\
\hline Years of Education & $\begin{array}{l}\text { Human Capital measured as the average years of } \\
\text { secondary schooling in total population. Source: Barro } \\
\text { and Lee (1996). See update version at: } \\
\text { http://www.cid.harvard.edu/ciddata.ciddata.html }\end{array}$ \\
\hline Loans/GDP & $\begin{array}{l}\text { Claims on the private sector, divided by GDP. Source: } \\
\text { International Financial Statistics, International } \\
\text { Monetary Fund }\end{array}$ \\
\hline Credit/GDP & $\begin{array}{l}\text { Domestic credit provided by banking sector divided } \\
\text { by GDP. Source: World Development Indicators, } \\
\text { World Bank. }\end{array}$ \\
\hline M2/GDP & $\begin{array}{l}\text { This measures includes the liquidity liabilities of the } \\
\text { financial system: they equals currency plus demand } \\
\text { and interest bearing liabilities of banks and non- } \\
\text { financial intermediaries divided by GDP. Source: } \\
\text { World Development Indicators, World Bank. }\end{array}$ \\
\hline Deposits/GDP & $\begin{array}{l}\text { This measure is defined as the sum of demand } \\
\text { deposits, time, saving and foreign currency deposits } \\
\text { divided by GDP. Source: International Financial } \\
\text { Statistics, International Monetary Fund }\end{array}$ \\
\hline
\end{tabular}

Note: This table describes the variables collected for our study. The first column gives the names of the variable as we use it; the second column describe the variables and provides the source from which it was collected. 
Table 2. Summary statistics, 5 year-averages for the period 1975-2002

\begin{tabular}{lcccccc}
\hline \hline \multicolumn{1}{c}{ Variable } & Mean & Median & $\begin{array}{c}\text { Standard } \\
\text { Deviation }\end{array}$ & Minimum & Maximum & $\begin{array}{c}\text { Number of } \\
\text { observations }\end{array}$ \\
\hline GDP growth & 1.2 & 1.3 & 3.4 & -14.2 & 11.0 & 306 \\
LogInvgdp & 3.0 & 3 & 0.3 & 1.6 & 3.8 & 306 \\
GovFiscalBal & -4.1 & -3.6 & 4.3 & -28.1 & 15.2 & 306 \\
Inflation & 16.8 & 9.5 & 28.5 & -2.3 & 273.6 & 306 \\
LogOpeness & 3.8 & 3.8 & 0.6 & 2.4 & 5.2 & 306 \\
LogPopGrowth & 0.6 & 0.8 & 0.7 & -2.8 & 1.6 & 306 \\
LogYearEdu & 1.2 & 1.4 & 0.7 & -2.0 & 2.4 & 306 \\
Rem/GDP & 2.9 & 1.5 & 4.0 & 0 & 22.6 & 306 \\
Loan/GDP & 27.7 & 22.6 & 20.4 & 2.4 & 133.3 & 305 \\
Credit/GDP & 47.1 & 31.8 & 31.8 & 0.9 & 193.8 & 306 \\
M2/GDP & 37.8 & 30.9 & 25.1 & 8.1 & 164.5 & 306 \\
Dep/GDP & 32.2 & 27.7 & 20.6 & 5.8 & 142.5 & 306 \\
\hline \hline
\end{tabular}

Note: This table reports the summary statistics of the main regression variables. Definition and data sources of the variables are in Table 2. Outliers have been excluded. 
Table 3: Bivariate Correlations of Variables of Interest

\begin{tabular}{|c|c|c|c|c|c|c|c|c|c|c|c|c|}
\hline & $\begin{array}{l}\text { GDP } \\
\text { growth }\end{array}$ & $\begin{array}{c}\text { Log } \\
\text { Invgdp }\end{array}$ & $\begin{array}{c}\text { Gov Fiscal } \\
\text { Balance }\end{array}$ & $\begin{array}{c}\text { Inflatio } \\
\mathrm{n}\end{array}$ & $\begin{array}{l}\text { Log } \\
\text { Openne } \\
\text { ss }\end{array}$ & $\begin{array}{l}\text { Log } \\
\text { PopGrowt } \\
\text { h }\end{array}$ & $\begin{array}{l}\text { LogYearEd } \\
\mathrm{u}\end{array}$ & $\begin{array}{l}\text { Rem/ } \\
\text { GDP }\end{array}$ & $\begin{array}{l}\text { Loan/ } \\
\text { GDP }\end{array}$ & $\begin{array}{l}\text { Credit } \\
\text { /GDP }\end{array}$ & $\begin{array}{c}\mathrm{M} 2 / \\
\mathrm{GD} \\
\mathrm{P}\end{array}$ & $\begin{array}{l}\text { Dep/ } \\
\text { GDP }\end{array}$ \\
\hline GDP growth & 1 & & & & & & & & & & & \\
\hline LogInvGdp & $0.43^{*}$ & 1 & & & & & & & & & & \\
\hline GovFiscalBal & $0.12^{*}$ & 0.09 & 1 & & & & & & & & & \\
\hline \multirow[t]{2}{*}{ Inflation } & & & - & & & & & & & & & \\
\hline & $-0.26 *$ & -0.04 & 0.00 & 1 & & & & & & & & \\
\hline LogOpenness & $0.15^{*}$ & $0.39 *$ & $0.11 *$ & $-0.28 *$ & 1 & & & & & & & \\
\hline \multirow[t]{2}{*}{ LogPopGrowth } & & & - & & & & & & & & & \\
\hline & $0.10^{*}$ & $-0.11 *$ & 0.06 & $-0.22 *$ & $-0.19 *$ & 1 & & & & & & \\
\hline LogYearEdu & 0.06 & $0.34 *$ & $0.14^{*}$ & $0.12 *$ & $0.32 *$ & $-0.48^{*}$ & 1 & & & & & \\
\hline Rem/GDP & $0.14^{*}$ & $0.19 *$ & $-0.19 *$ & $-0.16^{*}$ & $0.27 *$ & $0.14^{*}$ & 0.04 & 1 & & & & \\
\hline Loan/GDP & $0.18 *$ & $0.38 *$ & 0.06 & $-0.10 *$ & $0.33 *$ & $-0.23 *$ & $0.41 *$ & 0.07 & 1 & & & \\
\hline Credit/GDP & 0.05 & $0.28 *$ & $-0.17 *$ & 0.06 & $0.22 *$ & $-0.15^{*}$ & $0.35^{*}$ & 0.06 & $0.69 *$ & 1 & & \\
\hline M2/GDP & $0.23 *$ & $0.40^{*}$ & $-0.09 *$ & $-0.25^{*}$ & $0.42 *$ & $-0.19 *$ & $0.37^{*}$ & $0.27 *$ & $0.76^{*}$ & $0.64^{*}$ & 1 & \\
\hline \multirow[t]{2}{*}{ Dep/GDP } & & & & & & & & & & & 0.95 & \\
\hline & $0.21 *$ & $0.39 *$ & -0.08 & $-0.18^{*}$ & $0.41 *$ & $-0.27^{*}$ & $0.47^{*}$ & $0.22^{*}$ & $0.83^{*}$ & $0.67 *$ & * & 1 \\
\hline
\end{tabular}

Note: This table reports the correlation matrix of the main regression variables. Definitions and data sources of the variables are in

Table 2. Stars denote significance at 10 percent level or better. 
Table 4. Linear Growth Effects of Remittances

Dependent variable is GDP per capita growth

\begin{tabular}{llll}
\hline & OLS & FE & SGMM \\
\hline LogInGDP & $-0.698^{* * *}$ & $-5.896^{* * *}$ & -1.059 \\
& $(0.244)$ & $(0.992)$ & $(1.038)$ \\
LogPopGrowth & 0.214 & -0.911 & 0.057 \\
& $(0.404)$ & $(0.806)$ & $(0.544)$ \\
GovFiscalBal & $0.119 * *$ & $0.156^{* *}$ & 0.209 \\
& $(0.050)$ & $(0.064)$ & $(0.180)$ \\
LogInvGDP & $4.698^{* * *}$ & $5.232^{* * *}$ & $5.039 * * *$ \\
& $(0.571)$ & $(0.795)$ & $(1.138)$ \\
LogYearEdu & $0.668^{*}$ & -0.631 & 1.246 \\
& $(0.363)$ & $(0.854)$ & $(1.664)$ \\
LogOpennes & -0.338 & $1.171^{*}$ & $-1.147 *$ \\
& $(0.316)$ & $(0.687)$ & $(0.634)$ \\
Inflation & $-0.022^{* *}$ & -0.007 & $-0.035^{* *}$ \\
& $(0.010)$ & $(0.007)$ & $(0.015)$ \\
Rem/GDP & 0.043 & 0.022 & 0.010 \\
Constant & $(0.051)$ & $(0.087)$ & $(0.096)$ \\
& $-4.921^{* *}$ & $35.507 * * *$ & 0.034 \\
Observations & $(2.425)$ & $(8.892)$ & $(8.442)$ \\
R-squared & 315 & 315 & 315 \\
Number of countries & 0.35 & 0.68 & 0.31 \\
AR(1) test & & & 73 \\
AR(2) test & & & 0.00 \\
P-value Hansen test & & & 0.52 \\
\hline Robust standard & & 0.55 \\
\hline
\end{tabular}

Robust standard errors in parentheses, ${ }^{*}$ significant at $10 \%$; ${ }^{* *}$ significant at $5 \%$; ${ }^{* * *}$ significant at $1 \%$. All regressions include time dummies 
Table 5. Growth, Remittances and Financial Development, OLS estimates

Dependent variable is GDP per capita growth

\begin{tabular}{|c|c|c|c|c|}
\hline & DEP/GDP & LOAN/GDP & CREDIT/GDP & M2/GDP \\
\hline LogInGDP & $\begin{array}{l}-0.654 * * \\
(0.254)\end{array}$ & $\begin{array}{l}-0.661 \text { *** } \\
(0.255)\end{array}$ & $\begin{array}{l}-0.661 * * * \\
(0.245)\end{array}$ & $\begin{array}{l}-0.734 * * * \\
(0.244)\end{array}$ \\
\hline LogPopGrowth & $\begin{array}{l}0.368 \\
(0.418)\end{array}$ & $\begin{array}{l}0.262 \\
(0.419)\end{array}$ & $\begin{array}{l}0.242 \\
(0.413)\end{array}$ & $\begin{array}{l}0.333 \\
(0.419)\end{array}$ \\
\hline GovFiscalBal & $\begin{array}{l}0.134^{* * *} * \\
(0.052)\end{array}$ & $\begin{array}{l}0.116^{* *} \\
(0.050)\end{array}$ & $\begin{array}{l}0.090 \\
(0.055)\end{array}$ & $\begin{array}{l}0.133^{* *} \\
(0.053)\end{array}$ \\
\hline LogInvGDP & $\begin{array}{l}4.255^{* * *} \\
(0.701)\end{array}$ & $\begin{array}{l}4.312^{* * *} \\
(0.668)\end{array}$ & $\begin{array}{l}4.580^{* * *} \\
(0.611)\end{array}$ & $\begin{array}{l}4.091 * * * \\
(0.624)\end{array}$ \\
\hline LogYearEdu & $\begin{array}{l}0.524 \\
(0.371)\end{array}$ & $\begin{array}{l}0.573 \\
(0.368)\end{array}$ & $\begin{array}{l}0.695^{*} \\
(0.368)\end{array}$ & $\begin{array}{l}0.651 * \\
(0.364)\end{array}$ \\
\hline LogOpennes & $\begin{array}{l}-0.477 \\
(0.340)\end{array}$ & $\begin{array}{l}-0.356 \\
(0.341)\end{array}$ & $\begin{array}{l}-0.477 \\
(0.344)\end{array}$ & $\begin{array}{l}-0.493 \\
(0.324)\end{array}$ \\
\hline Inflation & $\begin{array}{l}-0.019 * * \\
(0.009)\end{array}$ & $\begin{array}{l}-0.019 * * \\
(0.009)\end{array}$ & $\begin{array}{l}-0.023^{* *} \\
(0.010)\end{array}$ & $\begin{array}{l}-0.018^{* *} \\
(0.009)\end{array}$ \\
\hline RemGDP & $\begin{array}{l}0.253^{* *} \\
(0.106)\end{array}$ & $\begin{array}{l}0.228^{* *} \\
(0.113)\end{array}$ & $\begin{array}{l}0.213^{*} \\
(0.112)\end{array}$ & $\begin{array}{l}0.197^{*} \\
(0.100)\end{array}$ \\
\hline DepGDP & $\begin{array}{l}0.032^{* * *} \\
(0.012)\end{array}$ & & & \\
\hline RemGDP*DepGDP & $\begin{array}{l}-0.004 * * \\
(0.002)\end{array}$ & & & \\
\hline LoanGDP & & $\begin{array}{l}0.024 * * \\
(0.010)\end{array}$ & & \\
\hline RemGDP*LoanGDP & & $\begin{array}{l}-0.005^{* *} \\
(0.002)\end{array}$ & & \\
\hline CreditGDP & & & $\begin{array}{l}0.008 \\
(0.008)\end{array}$ & \\
\hline RemGDP*CreditGDP & & & $\begin{array}{l}-0.003 * \\
(0.002)\end{array}$ & \\
\hline M2GDP & & & & $\begin{array}{l}0.025^{* * *} \\
(0.009)\end{array}$ \\
\hline RemGDP*M2GDP & & & & $\begin{array}{l}-0.003 * * \\
(0.001)\end{array}$ \\
\hline Constant & $\begin{array}{l}-4.253 \\
(2.780) \\
\end{array}$ & $\begin{array}{l}-4.612^{*} \\
(2.695)\end{array}$ & $\begin{array}{l}-4.967 * \\
(2.559)\end{array}$ & $\begin{array}{l}-3.156 \\
(2.606)\end{array}$ \\
\hline Observations & 306 & 305 & 307 & 314 \\
\hline R-squared & 0.36 & 0.35 & 0.34 & 0.35 \\
\hline
\end{tabular}

Robust standard errors in parentheses, * significant at 10\%; ** significant at 5\%; *** significant at $1 \%$. All regressions include time dummies 
Table 6. Growth, Remittances and Financial Development, SGMM estimates

Dependent variable is GDP per capita growth

\begin{tabular}{|c|c|c|c|c|}
\hline & DEP/GDP & LOAN/GDP & CREDIT/GDP & M2/GDP \\
\hline LogInGDP & $\begin{array}{l}-1.394^{*} \\
(0.745)\end{array}$ & $\begin{array}{l}-2.462^{* * *} \\
(0.897)\end{array}$ & $\begin{array}{l}-1.482^{*} \\
(0.755)\end{array}$ & $\begin{array}{l}-1.974 * * \\
(0.827)\end{array}$ \\
\hline LogPopGrowth & $\begin{array}{l}0.114 \\
(0.527)\end{array}$ & $\begin{array}{l}-0.141 \\
(0.561)\end{array}$ & $\begin{array}{l}-0.066 \\
(0.604)\end{array}$ & $\begin{array}{l}0.240 \\
(0.556)\end{array}$ \\
\hline GovFiscalBal & $\begin{array}{l}0.397 * * \\
(0.180)\end{array}$ & $\begin{array}{l}0.354 * * \\
(0.150)\end{array}$ & $\begin{array}{l}0.284^{*} \\
(0.153)\end{array}$ & $\begin{array}{l}0.306^{*} \\
(0.155)\end{array}$ \\
\hline LogInvGDP & $\begin{array}{l}3.200^{* * *} \\
(0.974)\end{array}$ & $\begin{array}{l}2.626^{* *} \\
(1.304)\end{array}$ & $\begin{array}{l}4.041^{* * *} \\
(1.219)\end{array}$ & $\begin{array}{l}3.629 * * * \\
(1.164)\end{array}$ \\
\hline LogYearEdu & $\begin{array}{l}1.245 \\
(1.120)\end{array}$ & $\begin{array}{l}2.555^{* *} \\
(1.268)\end{array}$ & $\begin{array}{l}1.198 \\
(1.238)\end{array}$ & $\begin{array}{l}2.516^{*} \\
(1.362)\end{array}$ \\
\hline LogOpennes & $\begin{array}{l}-1.425^{*} \\
(0.732)\end{array}$ & $\begin{array}{l}-1.444 \\
(0.935)\end{array}$ & $\begin{array}{l}-1.083^{*} \\
(0.603)\end{array}$ & $\begin{array}{l}-1.463^{*} \\
(0.775)\end{array}$ \\
\hline Inflation & $\begin{array}{l}-0.029 * * \\
(0.013)\end{array}$ & $\begin{array}{l}-0.024^{* *} \\
(0.011)\end{array}$ & $\begin{array}{l}-0.034^{* *} \\
(0.013)\end{array}$ & $\begin{array}{l}-0.027^{* *} \\
(0.013)\end{array}$ \\
\hline RemGDP & $\begin{array}{l}0.406^{* *} \\
(0.170)\end{array}$ & $\begin{array}{l}0.397^{* *} \\
(0.166)\end{array}$ & $\begin{array}{l}0.251^{*} \\
(0.134)\end{array}$ & $\begin{array}{l}0.389 * * \\
(0.153)\end{array}$ \\
\hline DepGDP & $\begin{array}{l}0.070^{* * *} \\
(0.022)\end{array}$ & & & \\
\hline RemGDP*DepGDP & $\begin{array}{l}-0.008^{* * *} \\
(0.003)\end{array}$ & & & \\
\hline LoanGDP & & $\begin{array}{l}0.084 * * * \\
(0.026)\end{array}$ & & \\
\hline RemGDP*LoanGDP & & $\begin{array}{l}-0.009 * * * \\
(0.003)\end{array}$ & & \\
\hline CreditGDP & & & $\begin{array}{l}0.034 * * * \\
(0.012)\end{array}$ & \\
\hline RemGDP*CreditGDP & & & $\begin{array}{l}-0.005^{* * * *} \\
(0.002)\end{array}$ & \\
\hline M2GDP & & & & $\begin{array}{l}0.047 * * * \\
(0.015)\end{array}$ \\
\hline RemGDP*M2GDP & & & & $\begin{array}{l}-0.006^{* * *} \\
(0.002)\end{array}$ \\
\hline Constant & $\begin{array}{l}7.874 \\
(6.419)\end{array}$ & $\begin{array}{l}15.870^{* *} \\
(7.863)\end{array}$ & $\begin{array}{l}4.840 \\
(7.566) \\
\end{array}$ & $\begin{array}{l}9.466 \\
(7.529)\end{array}$ \\
\hline Observations & 306 & 305 & 307 & 314 \\
\hline Number of countries & 72 & 71 & 73 & 73 \\
\hline $\mathrm{AR}(1)$ test & 0.00 & 0.00 & 0.00 & 0.00 \\
\hline $\operatorname{AR}(2)$ test & 1.00 & 0.78 & 0.91 & 0.75 \\
\hline P-value Hansen test & 0.86 & 0.77 & 0.77 & 0.57 \\
\hline R-squared & 0.23 & 0.10 & 0.24 & 0.21 \\
\hline
\end{tabular}

Robust standard errors in parentheses, * significant at $10 \%$; ** significant at $5 \%$; *** significant at $1 \%$.

All regressions include time dummies 
Table 7. Marginal Effect of Remittances on Growth by Levels of Financial Depth

Financial Depth at with $\mathrm{mg}$. effect of remittances is

DEP/GDP LOAN/GDP CREDIT/GDP M2/GDP

zero:

With investment 50.8

Without investment $\quad 57.2$

$50.8 \quad 44.1$

45.1

50.2

64.8

74.4

72.1

Marginal effect of remittances at:

Median level of Financial Depth

With investment

0.18

0.27

0.19

0.23

0.09

0.20

Without investment

0.15

0.15

0.21

0.29

Mean level of Financial Depth

With investment

0.23

0.17

0.02

0.16

Without investment

0.23

0.14

0.24

Notes: These statistics are based on SGMM estimates and are statistically significant at 5 percent significance level 
Table 8. Investment, Remittances and Financial Development, SGMM estimates

Dependent variable is Investment to GDP

\begin{tabular}{|c|c|c|c|c|}
\hline & DEP/GDP & LOAN/GDP & CREDIT/GDP & $\mathrm{M} 2 / \mathrm{GDP}$ \\
\hline Lagged InvGDP & $\begin{array}{l}0.874 * * * \\
(0.110)\end{array}$ & $\begin{array}{l}0.837 * * * \\
(0.095)\end{array}$ & $\begin{array}{l}0.865^{* * *} \\
(0.104)\end{array}$ & $\begin{array}{l}0.854^{* * *} \\
(0.110)\end{array}$ \\
\hline Real GDP Growth & $\begin{array}{l}0.534^{* *} \\
(0.214)\end{array}$ & $\begin{array}{l}0.518^{* * *} \\
(0.181)\end{array}$ & $\begin{array}{l}0.555^{* * *} \\
(0.189)\end{array}$ & $\begin{array}{l}0.528^{* *} \\
(0.208)\end{array}$ \\
\hline Lending rate & $\begin{array}{l}-0.014 \\
(0.019)\end{array}$ & $\begin{array}{l}-0.015 \\
(0.020)\end{array}$ & $\begin{array}{l}-0.021 \\
(0.019)\end{array}$ & $\begin{array}{l}-0.005 \\
(0.014)\end{array}$ \\
\hline RemGDP & $\begin{array}{l}0.398^{*} \\
(0.231)\end{array}$ & $\begin{array}{l}0.710^{* *} \\
(0.341)\end{array}$ & $\begin{array}{l}0.507^{* *} \\
(0.242)\end{array}$ & $\begin{array}{l}0.690 * * \\
(0.295)\end{array}$ \\
\hline DepGDP & $\begin{array}{l}0.027 \\
(0.038)\end{array}$ & & & \\
\hline RemGDP*DepGDP & $\begin{array}{l}-0.006^{* *} \\
(0.003)\end{array}$ & & & \\
\hline LoanGDP & & $\begin{array}{l}0.052 \\
(0.047)\end{array}$ & & \\
\hline RemGDP*LoanGDP & & $\begin{array}{l}-0.012^{* *} \\
(0.006)\end{array}$ & & \\
\hline CreditGDP & & & $\begin{array}{l}0.017 \\
(0.026)\end{array}$ & \\
\hline RemGDP*CreditGDP & & & $\begin{array}{c}-0.005^{*} \\
(0.003)\end{array}$ & \\
\hline M2GDP & & & & $\begin{array}{l}0.054 \\
(0.039)\end{array}$ \\
\hline RemGDP*M2GDP & & & & $\begin{array}{l}-0.008^{* *} \\
(0.003)\end{array}$ \\
\hline Constant & $\begin{array}{l}-1.471 \\
(2.054)\end{array}$ & $\begin{array}{l}-1.726 \\
(2.476)\end{array}$ & $\begin{array}{l}-0.974 \\
(2.554)\end{array}$ & $\begin{array}{l}-2.405 \\
(2.302)\end{array}$ \\
\hline Observations & 343 & 344 & 343 & 350 \\
\hline Number of countries & 109 & 110 & 112 & 112 \\
\hline $\operatorname{AR}(1)$ test & 0.00 & 0.00 & 0.00 & 0.00 \\
\hline $\operatorname{AR}(2)$ test & 0.83 & 0.78 & 0.89 & 0.87 \\
\hline P-value Hansen test & 0.81 & 0.76 & 0.80 & 0.81 \\
\hline R-squared & 0.58 & 0.54 & 0.56 & 0.58 \\
\hline
\end{tabular}

Robust standard errors in parentheses, ${ }^{*}$ significant at $10 \%$; ${ }^{* *}$ significant at $5 \%$; ${ }^{* * *}$ significant at $1 \%$.

All regressions include time dummies 
Table 9. Marginal Impact of Remittances on Growth Below and Above the Median Level of Financial Depth

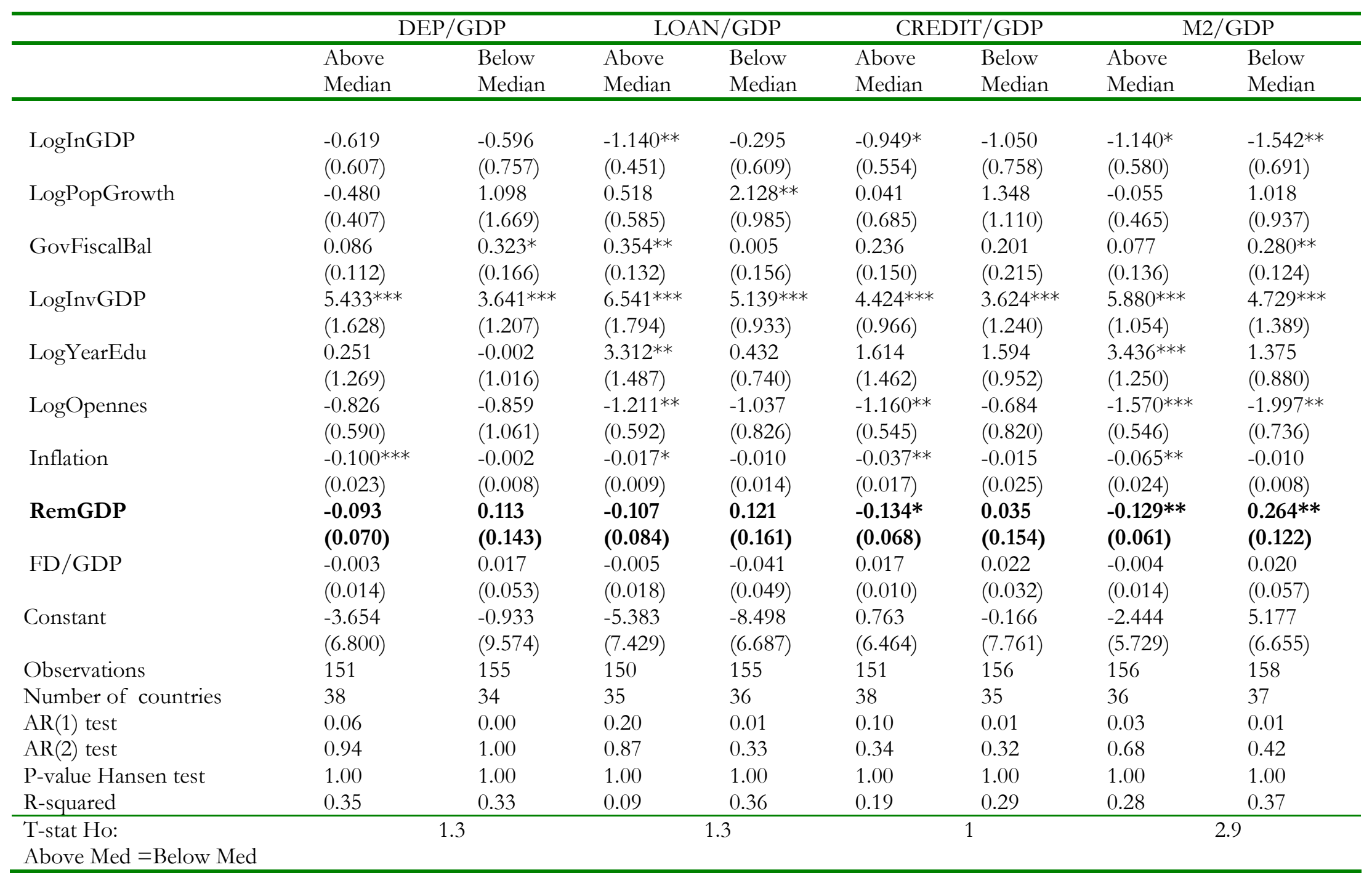

Robust standard errors in parentheses, * significant at 10\%; ** significant at 5\%; *** significant at 1\%. All regressions include time dummies 
Table 10. Threshold Estimation

\begin{tabular}{|c|c|c|c|c|c|c|c|c|}
\hline \multirow[b]{2}{*}{ Estimated threshold } & \multicolumn{2}{|c|}{ DEP/GDP } & \multicolumn{2}{|c|}{ LOAN/GDP } & \multicolumn{2}{|c|}{ CREDIT/GDP } & \multicolumn{2}{|c|}{ M2/GDP } \\
\hline & $>22.6 \%$ & $\leq 22.6 \%$ & $>20.8 \%$ & $\leq 20.8 \%$ & $>30 \%$ & $\leq 30 \%$ & $>20.8 \%$ & $\leq 20.8 \%$ \\
\hline \multirow[t]{2}{*}{ LogInGDP } & -0.407 & $-1.707^{* * *} *$ & $-0.608 * *$ & -0.598 & $-0.661 * *$ & $-1.259 * *$ & $-0.727^{* * *} *$ & $-1.577 * *$ \\
\hline & $(0.297)$ & $(0.440)$ & $(0.304)$ & $(0.375)$ & $(0.265)$ & $(0.484)$ & $(0.266)$ & $(0.615)$ \\
\hline \multirow[t]{2}{*}{ LogPopGrowth } & 0.105 & $2.460 * *$ & -0.376 & $2.182^{* * *}$ & -0.320 & $2.325^{* * *}$ & -0.137 & $2.918 * *$ \\
\hline & $(0.431)$ & $(0.977)$ & $(0.361)$ & $(0.721)$ & $(0.377)$ & $(0.817)$ & $(0.410)$ & $(1.110)$ \\
\hline \multirow[t]{2}{*}{ GovFiscalBal } & 0.062 & $0.294 * * *$ & 0.123 & 0.065 & 0.048 & $0.277 * *$ & 0.094 & $0.382 * *$ \\
\hline & $(0.069)$ & $(0.074)$ & $(0.089)$ & $(0.065)$ & $(0.059)$ & $(0.123)$ & $(0.058)$ & $(0.146)$ \\
\hline \multirow[t]{2}{*}{ LogInvGDP } & $5.536 * * *$ & $3.264 * *$ & $5.184 * * *$ & $4.951 * * *$ & $5.825^{* * *}$ & $3.648^{* * *}$ & $4.546^{* * *}$ & $3.656 * *$ \\
\hline & $(0.788)$ & $(1.244)$ & $(0.878)$ & $(1.037)$ & $(0.756)$ & $(0.696)$ & $(0.729)$ & $(1.574)$ \\
\hline \multirow[t]{2}{*}{ LogYearEdu } & 0.832 & 0.984 & 0.458 & 0.786 & 0.374 & $1.374^{* *}$ & 0.601 & 1.145 \\
\hline & $(0.515)$ & $(0.622)$ & $(0.549)$ & $(0.527)$ & $(0.528)$ & $(0.578)$ & $(0.397)$ & $(0.877)$ \\
\hline \multirow[t]{2}{*}{ LogOpennes } & -0.275 & $-1.919 * * *$ & -0.509 & -0.598 & -0.158 & $-1.570 * *$ & -0.173 & -1.541 \\
\hline & $(0.374)$ & $(0.648)$ & $(0.376)$ & $(0.630)$ & $(0.362)$ & $(0.645)$ & $(0.342)$ & $(1.093)$ \\
\hline \multirow[t]{2}{*}{ Inflation } & -0.018 & 0.011 & $-0.022 *$ & -0.010 & $-0.017^{*}$ & 0.001 & -0.016 & 0.012 \\
\hline & $(0.012)$ & $(0.012)$ & $(0.012)$ & $(0.011)$ & $(0.010)$ & $(0.015)$ & $(0.013)$ & $(0.016)$ \\
\hline \multirow[t]{2}{*}{ RemGDP } & 0.027 & 0.212 & 0.052 & 0.178 & -0.004 & $0.216 * *$ & 0.018 & $0.467 * *$ \\
\hline & $(0.053)$ & $(0.161)$ & $(0.058)$ & $(0.119)$ & $(0.052)$ & $(0.104)$ & $(0.052)$ & (0.195) \\
\hline \multirow[t]{2}{*}{ FD/GDP } & 0.006 & $0.152^{*}$ & 0.007 & $-0.124^{* *}$ & $-0.012^{*}$ & -0.058 & 0.011 & 0.069 \\
\hline & $(0.010)$ & $(0.089)$ & $(0.010)$ & $(0.061)$ & $(0.007)$ & $(0.051)$ & $(0.009)$ & $(0.142)$ \\
\hline \multirow[t]{2}{*}{ Constant } & $-10.569 * * *$ & 7.417 & $-5.683^{*}$ & -6.542 & $-8.289 * * *$ & 5.030 & $-5.336^{*}$ & 4.247 \\
\hline & $(2.988)$ & $(5.573)$ & $(3.289)$ & $(4.260)$ & $(2.912)$ & $(4.378)$ & $(2.820)$ & $(7.776)$ \\
\hline Observations & 199 & 107 & 169 & 137 & 206 & 101 & 247 & 67 \\
\hline R-squared & 0.33 & 0.56 & 0.38 & 0.41 & 0.41 & 0.48 & 0.31 & 0.58 \\
\hline F-test for no threshold & \multicolumn{2}{|c|}{32.16} & \multicolumn{2}{|c|}{38.94} & \multicolumn{2}{|c|}{56.25} & \multicolumn{2}{|c|}{42.14} \\
\hline Bootstrap P-value & \multicolumn{2}{|c|}{0.017} & & 04 & \multicolumn{2}{|c|}{0.000} & \multicolumn{2}{|c|}{0.000} \\
\hline
\end{tabular}

Threshold estimation based on Hansen (2000). Robust standard errors in parentheses, * significant at $10 \%$; ** significant at 5\%; *** significant at $1 \%$. All regressions include time dummies 


\section{Table 11. Cyclical Behavior of Remittances and Financial Depth}

\begin{tabular}{lllll}
\hline & DEP/GDP & LOAN/GDP & CREDIT/GDP & M2/GDP \\
\hline Correlations 1/ & $-0.18^{*}$ & $-0.16^{*}$ & -0.13 & $-0.17^{*}$ \\
Reg Estimates 2/ & $-0.29^{*}$ & $-0.35^{*}$ & -0.18 & $-0.23^{*}$ \\
\hline
\end{tabular}

Notes: 1/ Displays pairwise correlation coefficients between the cyclical indicator of remittances in Figure 4 and the median over the period 1975-2002 of each of the financial depth (FD) variables for 116 developing countries. 2/ Displays regression estimates from OLS regressions of the cyclical indicator of remittances and each of the FD variables. A star denotes significance at the $10 \%$ level or better. 
Appendix 1. Definitions of the Remittance Variable

The analysis of the impact of remittances uses a panel of 70 developing countries, during the period 1975-2002.

Unless otherwise indicated, total remittances are constructed as the sum of three items in the

IMF's Balance of Payment Statistics Yearbook (BOPSY): "Workers' Remittances", "Compensation of Employees" and "Migrant Transfers".

Workers' Remittances (part of current transfer in the current account) are current transfers made by migrants who are employed and resident in another economy. This typically includes those workers who move to an economy and stay, or are expexted to stay, a year or longer.

Compensation of Employees (part of the income component of the current account) instead comprises wages, salaries and other benefits (cash or in kind) earned by nonresident workers for work performed for residents of other countries. Such workers typically include border and seasonal workers, together with some other categories, e.g., local embassy staff.

Migrant Transfer (part of the capital account) include financial items that arise from the migration (change of residence) of individuals from one economy to another.

Following the country-specific notes in the BOPSY, Compensation of Employees is excluded from total remittances for the following countries: Argentina, Azerbajian, Barbados, Belize, Benin, Brazil, Cambodia, Cape Verde, China, Cote d'Ivoire, Dominican Republic, Ecuador, El Salvador, Guyana, Panama, Rwanda, Senegal, Seychelles, Turkey and Venezuela. Moreover the BOPSY specifies that migrants; transfer are recorded under "Other Current Transfers” for Kenia, Malaysia and the Syrian Arab Republic.

Additional adjustments or additions to the series were made on the basis of information received from IMF country desks and national authorities, as follows:

1. Bosnia and Herzegovina: desk provided data from 1998-2003

2. Bulgaria: Other current transfers are included in remittances 
3. Caribbean ${ }^{19}$ : Desk provided data for 1991-2002

4. I.R. of Iran: Other current transfers are used as figure for remittances

5. Lebanon: Desk provided data for 1997-2003

6. Lesotho: Desk provided data for 1982-2003

7. Macedonia, FYR: Desk provided data for 1993-1997

8. Moldova: Desk provided data for 2000

9. Niger: Desk provided data for 1995-2003

10. Romania: Desk provided data for 2000-2003

11. Slovak Republic: Desk provided data for 1999-2003

12. Tajikistan: Desk provided data for 1997-2001

13. Ukraine: Desk provided data for 2000

14. Venezuela: desk provided data for 1997-2003

19 The Caribbean region includes Antigua and Barbuda, Barbados, Belize, Dominica, the Dominican Republic, Grenada, Guyana, Haiti, Jamaica, St. Kitts and Nevis, St. Lucia, St. Vincent and the Grenadines, Suriname and Trinidad and Tobago. 
Appendix 2: Sample of countries

\begin{tabular}{|l|l|}
\hline \multicolumn{2}{|c|}{ Country } \\
\hline Argentina & Mexico \\
Barbados & Mozambique \\
Benin & Nepal \\
Bolivia & Nicaragua \\
Botswana & Niger \\
Brazil & Pakistan \\
Cameroon & Panama \\
Chile & Paraguay \\
China & Peru \\
Colombia & Philippines \\
Costa Rica & Poland \\
Croatia & Romania \\
Dominica & Russia \\
Dominican Republic & Samoa \\
Ecuador & Senegal \\
Egypt & Seychelles \\
El Salvador & Sierra Leone \\
Eritrea & Slovak Republic \\
Estonia & Slovenia \\
Ethiopia & South Africa \\
Guatemala & Sri Lanka \\
Guyana & St. Kitts and Nevis \\
Haiti & St. Lucia \\
Honduras & Sudan \\
Hungary & Swaziland \\
India & Syrian Arab Rep. \\
Indonesia & Thailand \\
Iran, Islamic Rep. of & Togo \\
Jamaica & Tonga \\
Kenya & Trinidad and Tobago \\
Malawi & Tunisia \\
Malaysia & Turkey \\
Mali & Uruguay \\
Malta & Venezuela \\
Mauritania & \\
Mauritius & \\
& \\
\hline
\end{tabular}

